\title{
Breastfeeding Duration and Related Factors among Mothers in Southeast Nigeria
}

\section{Uchenna Ekwochi ${ }^{1}$, Ebelechuku Francesca Ugochukwu ${ }^{2}$, Chinyere Ukamaka Onubogu ${ }^{3}$, Chuka Manyike ${ }^{4}$, Ihuoma Kathleen Ukpabi ${ }^{5}$, Kenneth Nchekwube Okeke ${ }^{6}$}

\author{
${ }^{1}$ Senior Lecturer and Consultant Paediatrician, Department of Paediatrics, College of Medicine, Enugu State \\ University of Science and Technology, Enugu, Nigeria. \\ ${ }^{2}$ Professor and Consultant Paediatrician, Department of Paediatrics, Faculty of Medicine, Nnamdi Azikiwe \\ University, Awka, Nigeria. \\ ${ }^{3}$ Lecturer and Consultant Paediatrician, Department of Paediatrics, Faculty of Medicine, Nnamdi Azikiwe \\ University, Awka, Nigeria. \\ ${ }^{4}$ Consultant Paediatrician, Department of Paediatrics, Ebonyi State University Teaching Hospital, Abakaliki, \\ Nigeria. \\ ${ }^{5}$ Consultant Paediatrician, Department of Paediatrics, Federal Medical Centre, Umuahia, Nigeria. \\ ${ }^{6}$ Lecturer and Consultant Paediatrician, Department of Paediatrics, Faculty of Medicine, Nnamdi Azikiwe \\ University, Awka, Nigeria.
}

Corresponding Author: Ebelechuku Francesca Ugochukwu

\begin{abstract}
Background: Breastfeeding is beneficial to mothers, infants and society at large. The nutritional and non-nutritional benefits are gained when practiced in line with recommended durations.

Objective: The duration of breastfeeding and related factors among mothers of Southeastern Nigeria were explored.

Methods: This was a hospital based cross-sectional study using an interviewer-administered questionnaire. Data analysis employed SPSS version 20.

Results: A total of 1,833 women were surveyed. Most (93.3\%) were aged 20-40 years and had at least secondary education $(94,6 \%)$. More than half $(64.3 \%)$ were working class. Many had 1-4 children $(91.5 \%)$ and a family size of $\leq 6(74.2 \%)$. Up to $83.3 \%$ of the mothers breastfed for $\geq 12$ months. Common reasons advanced for cessation of breastfeeding were pregnancy (29.8\%), baby refusing to suckle $(10.2 \%)$ or old enough to stop breastfeeding (18.0\%). No reason for cessation was given for $22.4 \%$. Mothers <20 years practiced non-exclusive breastfeeding or early introduction of complementary feeds, bottle-fed and were significantly least likely to breastfeed for up to one year.

Conclusion: A suboptimal number of Nigerian mothers breastfed for $\geq 12$ months. Unscientific reasons were proffered for cessation of breastfeeding. Younger mothers practiced non-exclusive breastfeeding, bottle-fed and gave early complementary feeds, negatively affecting duration of breastfeeding. Sustained individualized health education is advocated to improve duration of breastfeeding and avail young children of its wholesome nutritional benefits.
\end{abstract}

Keywords: Breastfeeding Cessation, Breastfeeding Duration, Lactation Cessation Determinants, Weaning Timing, Nutrition

\section{INTRODUCTION}

Human breast milk is the optimal nutrient for the infant and young child in the early period of life. ${ }^{[1]}$ It has both nutritive and non-nutritive values. Nutritionally it serves as a rich source of macronutrients such as carbohydrate, protein and fats $(3.8 \%$ fat, $1.0 \%$ protein, and $7 \%$ lactose, $87 \%$ water ${ }^{[2]}$ and micronutrients which includes but are not limited to iron, zinc, and copper. 
[3] Among the non-nutritive value of breastfeeding are: social bonding of motherinfant dyad, anti-allergic effect, antidiarrhea, reduction in the risk of maternal and childhood cancers such as ovarian and breast cancers, childhood leukemia. ${ }^{[4-8]}$ Studies have associated breastfeeding with higher neurodevelopmental and cognitive scores in children. ${ }^{[9,10]}$ For mother and child to achieve maximum benefits from breastfeeding, it is important that breastfeeding be practiced up to the recommended duration. A study has shown that each month of breastfeeding reduces the relative risk of ovarian cancer by $2 \%$. ${ }^{[6]}$ Also there exists a close link between extended breastfeeding and higher IQ scores, school attainment and higher earnings. ${ }^{[11]}$

On the other hand, suboptimal breastfeeding accounts for over 30\% of child deaths in low-income countries $[12,13]$ and is linked with national gross economic losses. [14] The WHO and UNICEF recommended exclusive breast feeding for the first 6-months of life and introduction of adequate complementary feed afterwards while continuing to breastfeed into the $2^{\text {nd }}$ year and beyond. ${ }^{[15]}$ In the background of the myriad benefits of optimal breastfeeding to the mother, child and society, it behooved the researchers to explore how optimally the mothers of southeast Nigeria practiced breastfeeding and factors related to such practices. The findings would serve as a veritable tool in designing programs to promote and protect optimal breastfeeding in the region.

\section{SUBJECTS AND METHODS}

This hospital based cross-sectional study was conducted across the five states of the South-East geopolitical zone of Nigeria in 13 health facilities - namely, Nnamdi Azikiwe University Teaching Hospital, Nnewi; Iyienu Hospital, Ogidi; Waterside Specialist Hospital, Onitsha; Federal Medical Centre, Owerri; Ebonyi State University Teaching Hospital, Abakaliki; Enugu State University Teaching
Hospital, Enugu; Chukwuemeka Odumegwu Ojukwu University Teaching Hospital, Awka; St. Charles Borromeo Specialist Hospital, Onitsha; Awka-Etiti Catholic Mission Hospital, Awka-Etiti; Immaculate Heart Hospital, Nkpor; St. Patrick's Hospital, Enugu; Uwani Health Centre, Enugu and Federal Medical Centre, Umuahia. The South East region of Nigeria comprises Anambra, Enugu, Imo, Abia and Ebonyi states. Southeasterners are of the Igbo tribe and the dominant religion is Christianity. The Southeast occupies a land mass of $28.98 \mathrm{~m}^{2}$ with population of 16.39 million people $(11.68 \%$ of national population) according to 2006 national population census. Women make up $49 \%$ of the population.

The study was conducted over a period of 3 months between July and September, 2018. In each of the states, the major Baby Friendly health facilities that offered maternal and child health services were selected. Mothers were enrolled consecutively following an oral informed consent.

\section{Inclusion Criteria}

To be included in the study the woman must be of child-bearing age with the last offspring less than 24 months, and must have presented to the clinic with the index baby.

\section{Exclusion Criteria}

Non-biologic mothers and caregivers were excluded from the study.

\section{Instruments and Tools}

Data was collected from mothers attending well-baby (Immunization) clinics using an interviewer-administered questionnaire. The following sociodemographic characteristics of the subjects were obtained: Age in years categorized into $<20, \quad 20-30, \quad 31-40$ and >40, Highest Educational Level (No formal education, Primary Education, Secondary Education, and Post-Secondary Education), Occupation (Professional, Civil/ Public Servant, Trader, 
Artisan, Unskilled Worker, Peasant farmer and Unemployed), Parity (1-2, 3-4, 5-6, $\geq 7$ Children) and total family size categorized into $\leq 6$ and $>6$. Other measures ascertained from the participant were whether or not they practiced Exclusive breast feeding, total duration of breastfeeding in months $(<6, \geq 6$ to $<12, \geq 12$ to $<18, \geq 18)$ and reasons for cessation of breastfeeding.

\section{Data Analysis}

Data was analyzed using SPSS version 20. The relationship between two categorical variables or a categorical and an ordinal variable was examined using chisquare test while Kendall's tau-b was used to test the association between two ordinal variables. Any p-value less than 0.05 was considered statistically significant.

\section{RESULTS}

Table 1. Socio-demographic characteristics of the mothers

\begin{tabular}{|l|l|l|}
\hline Characteristics & Frequency & Percent \\
\hline Age (years) & & \\
<20 & 62 & 3.4 \\
$20-30$ & 944 & 51.5 \\
$31-40$ & 767 & 41.8 \\
$>40$ & 60 & 3.3 \\
\hline Highest Educational Level & & \\
No formal education & 36 & 2.0 \\
Primary education & 62 & 3.4 \\
Secondary education & 616 & 33.6 \\
Post-secondary education & 1119 & 61.0 \\
\hline Occupation & & \\
Professional & 209 & 11.4 \\
Civil/public servant & 554 & 30.2 \\
Trader & 416 & 22.7 \\
Artisan & 149 & 8.1 \\
Unskilled worker & 75 & 4.1 \\
Peasant farmer & 41 & 2.2 \\
Unemployed & 389 & 21.2 \\
\hline Parity & & \\
1 to 2 & 931 & 50.8 \\
3 to 4 & 746 & 40.7 \\
5 to 6 & 141 & 7.7 \\
$\geq 7$ & 15 & 0.8 \\
\hline Total family size & & \\
$\leq 6$ & 1360 & 74.2 \\
$>6$ & 473 & 25.8 \\
\hline Total & 1833 & 100.0 \\
\hline
\end{tabular}

Majority of the mothers were between 20 to 40 years of age $(93.3 \%)$, had at least secondary school education (94.6\%), working $(78.8 \%)$ and had a total family size of 6 persons or less. Table 1 outlines the characteristics of the subjects.
Mothers who exclusively breastfed constituted $37.3 \%$, while $83.3 \%$ breastfed for 12 months or more. Common reasons cited for cessation of breastfeeding were pregnancy $(29.8 \%)$, baby refusing to suckle $(10.2 \%)$ or old enough to stop breastfeeding (18.0\%). About $22.4 \%$ of mother gave no specific reason for stopping breastfeeding. This is shown in Table 2.

Table 2. Duration of breastfeeding and reasons for cessation of breastfeeding

\begin{tabular}{|l|l|l|}
\hline Breastfeeding practice & Frequency & Percent \\
\hline $\begin{array}{l}\text { Exclusive breastfeeding } \\
\text { Yes }\end{array}$ & 683 & \\
No & 1150 & 37.3 \\
\hline $\begin{array}{l}\text { Total duration of breastfeeding } \\
\text { (months) }\end{array}$ & & 62.7 \\
$<6$ & 68 & \\
$\geq 6$ to $<12$ & 238 & 3.7 \\
$\geq 12$ to $<18$ & 1516 & 13.0 \\
$\geq 18$ & 11 & 82.7 \\
\hline Reason for cessation of breastfeeding & & 0.6 \\
Pregnancy & 546 & \\
Recommencement of sexual activity & 130 & 29.8 \\
Use of contraceptives & 48 & 7.1 \\
Baby refused to suckle & 187 & 2.6 \\
Breastmilk became 'spoilt' & 17 & 10.2 \\
Baby was old enough to stop & 330 & 0.9 \\
breastfeeding & & 18.0 \\
Breastmilk was not enough for baby & 66 & \\
Need to return to work or school & 72 & 3.6 \\
Health problems & 27 & 3.9 \\
No specific reason & 410 & 1.5 \\
\hline Total & 1833 & 22.4 \\
\hline
\end{tabular}

Mothers less than twenty years old were significantly least likely to breastfeed for up to one year. Mothers that practiced non-exclusive breastfeeding, bottle feeding and early introduction of complementary feeds were significantly least likely to breastfeed for up to one year. The factors associated with duration of breastfeeding are outlined in Table 3.

Among mothers who did not breastfeed for up to one year, the commonest reasons cited for cessation of breastfeeding were pregnancy $(27.1 \%)$, return to sexual activity or need to use contraceptives (12.4\%), baby refusal to suck $(9.5 \%)$, need to return to work $(8.8 \%)$ or breastmilk inadequate for baby (6.9\%). Baby was considered old enough to stop breastfeeding by $10.8 \%$ of them. (Figure 1). 
Uchenna Ekwochi et.al. Breastfeeding duration and related factors among mothers in Southeast Nigeria.

Table 3. Factors associated with breastfeeding duration

\begin{tabular}{|c|c|c|c|}
\hline $\begin{array}{l}\text { Characteristics } \\
\text { Age }\end{array}$ & \multicolumn{2}{|c|}{$\begin{array}{l}\text { Total Breastfeeding duration } \\
<12 \text { months } \quad \geq 12 \text { months }\end{array}$} & p-Value \\
\hline $\begin{array}{l}\text { Age } \\
<20 \\
20-30 \\
31-40 \\
>40 \\
\end{array}$ & $\begin{array}{l}17(27.4) \\
166(17.6) \\
114(14.9) \\
9(15.0) \\
\end{array}$ & $\begin{array}{l}45(72.6) \\
778(82.4) \\
653(85.1) \\
51(85.0) \\
\end{array}$ & $0.029^{\mathrm{a}^{*}}$ \\
\hline $\begin{array}{l}\text { Highest educational level } \\
\text { No formal education } \\
\text { Primary education } \\
\text { Secondary education } \\
\text { Post-secondary education }\end{array}$ & $\begin{array}{l}7(19.4) \\
6(9.7) \\
93(15.1) \\
200(17.9)\end{array}$ & $\begin{array}{l}29(80.6) \\
56(90.3) \\
523(84.9) \\
919(82.1)\end{array}$ & $0.077^{\mathrm{a}}$ \\
\hline $\begin{array}{l}\text { Occupation } \\
\text { Professionals } \\
\text { Civil/public servants } \\
\text { Traders } \\
\text { Artisans } \\
\text { Unskilled workers } \\
\text { Peasant farmers } \\
\text { Unemployed } \\
\end{array}$ & $\begin{array}{l}21(10.0) \\
104(18.8) \\
77(18.5) \\
20(13.4) \\
7(9.3) \\
1(2.4) \\
76(19.5) \\
\end{array}$ & $\begin{array}{l}188(90.0) \\
450(81.2) \\
339(81.5) \\
129(86.6) \\
68(90.7) \\
40(97.6) \\
313(80.5) \\
\end{array}$ & $0.001^{\mathrm{b} *}$ \\
\hline $\begin{array}{l}\text { Parity } \\
1 \text { to } 2 \\
3 \text { to } 4 \\
\geq 5\end{array}$ & $\begin{array}{l}146(15.7) \\
144(19.3) \\
16(10.3)\end{array}$ & $\begin{array}{l}785(84.3) \\
602(80.7) \\
140(89.7) \\
\end{array}$ & $0.644^{\mathrm{a}}$ \\
\hline $\begin{array}{l}\text { Family size } \\
\leq 6 \\
>6\end{array}$ & $\begin{array}{l}234(17.2) \\
72(15.2)\end{array}$ & $\begin{array}{l}1126(82.8) \\
401(84.8)\end{array}$ & $0.307^{\mathrm{a}}$ \\
\hline $\begin{array}{l}\text { Exclusive breastfeeding practice } \\
\text { Yes } \\
\text { No }\end{array}$ & $\begin{array}{l}89(13.0) \\
217(18.9)\end{array}$ & $\begin{array}{l}594(87.0) \\
933(81.1)\end{array}$ & $0.001^{\mathrm{b} *}$ \\
\hline $\begin{array}{l}\text { Complementary feeding commencement age } \\
<6 \text { months } \\
\text { At } 6 \text { months } \\
>6 \text { months }\end{array}$ & $\begin{array}{l}154(24.1) \\
138(14.0) \\
14(6.7)\end{array}$ & $\begin{array}{l}485(75.9) \\
846(86.0) \\
196(93.3)\end{array}$ & $<0.001^{\mathrm{a}^{*}}$ \\
\hline $\begin{array}{l}\text { Bottle feeding } \\
\text { Yes } \\
\text { No }\end{array}$ & $\begin{array}{l}200(20.0) \\
106(12.8)\end{array}$ & $\begin{array}{l}802(80.0) \\
725(87.2)\end{array}$ & $<0.001^{\mathrm{b} *}$ \\
\hline Total & 306 & $1527(83.3)$ & $1833(100.0)$ \\
\hline
\end{tabular}

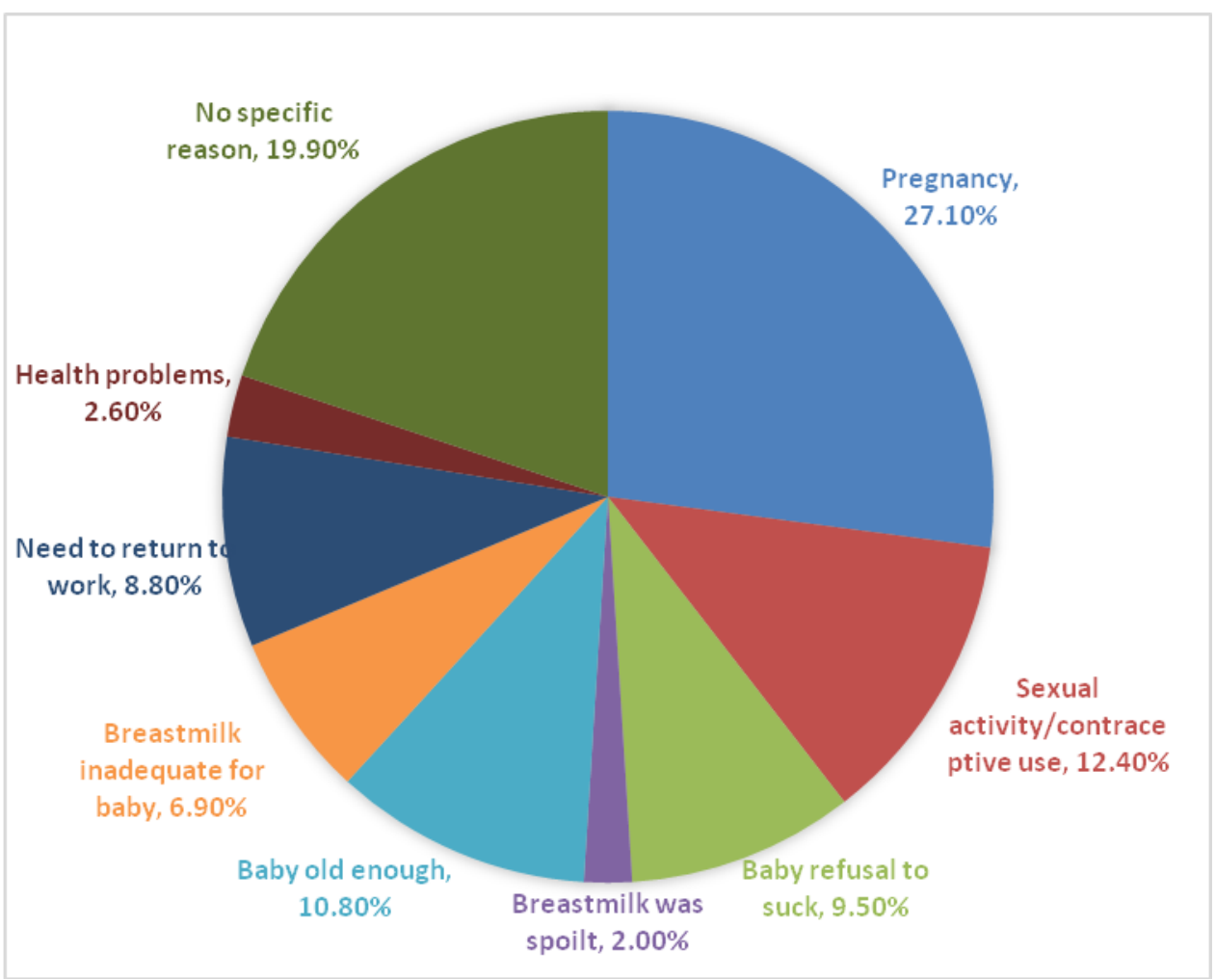

Figure 1. Reasons for breastfeeding cessation before one year $(n=306)$ 


\section{DISCUSSION}

A good number of mothers in the South-Eastern region of Nigeria breast feed their babies for up to 1 year and above. This duration of breastfeeding appears encouraging and consistent with a similarly high rate documented by Akadri et al in the South-West, ${ }^{[16]}$ Oni in the North-Central city of Ilorin, ${ }^{[17]}$ another study in the Northwest sate of Katsina ${ }^{[18]}$ and other international studies. ${ }^{[\mathbf{1 9 , 2 0 ]}}$ However, this is contrary to lower durations reported by Isenalumhe and Oviawe in Benin ${ }^{[21]}$ and another study in Delta and Edo States ${ }^{[22]}$ all of the South-South Nigeria. The observed difference in these regions could be the influence of different socioeconomic and environmental backgrounds of the mothers. There seems to be a progressive decline in the proportion of mothers who breastfed for upwards of 12 months in southern Nigeria (97.1\% to $89.9 \%$ from 1990 to 2008 ), ${ }^{[23]}$ further highlighted by this study $(83.3 \%)$ as against 89.9 in 2008. [23] This trend is worrisome as it undermines the gains of breastfeeding on child survival in developing countries. Therefore, urgent steps are needed to address the factors responsible for decline in the duration of breastfeeding among mothers in southern Nigeria.

Although most of our participants breastfed their babies for 1 year and above, only $0.6 \%$ breastfed beyond 18 months. This falls below the WHO and UNICEF standard which recommend continued breastfeeding up to 2 years of age or beyond. ${ }^{[15]}$ The fact that both local and international observations are documenting suboptimal compliance to WHO/UNICEF recommendation on breastfeeding duration calls for a more concerted effort into unraveling the cause of the suboptimal compliance. Among our participants, common reasons for cessation of breastfeeding earlier than recommended period include pregnancy occurring during breastfeeding, baby old enough to stop breastfeeding and baby voluntarily refusing to suckle. The belief in our society that a pregnant mother should not breastfeed is non-scientific and indeed needs to be addressed in public health campaigns. For mothers in our environment to stop breastfeeding earlier than standard timing on the ground that baby is old enough to stop breastfeeding reveals that these mothers were obviously uninformed of the standard globally recommended duration of breastfeeding as well as the benefits of breastfeeding to both the mother and the baby. There has to be a paradigm change in perception and practice of these mothers.

It is also interesting to note that in our study, mothers reported voluntary refusal to suckle otherwise known as breastfeeding strike as a major cause of early cessation of breastfeeding. This phenomenon has been reported in an earlier study. ${ }^{[24]}$ The fact that the study recorded a lower incidence compared to ours has demonstrated unhealthy increase of this practice in our environment. According to their study, older mothers, those with more children, higher occupational grades and higher educational attainment were more likely to experience infant refusal of breastfeeding before 6 months of age. In our opinion, the above maternal characteristics are likely to increase maternal stress and reduce their availability to breastfeed on demand. Thus, such mothers tend to introduce breast-milk substitutes and complementary feeds too early. This may distract the baby from breastfeeding and finally lead to early cessation. The above suggestions notwithstanding, there should still be a concerted effort to discover why an infant will voluntarily abandon the natural meal which should ordinarily appeal to its taste. Authors strongly believe the existence of a subtle deterrent which can only be unraveled through a more thorough review.

In our study, maternal age less than twenty years, non-exclusive breastfeeding, bottle feeding and early introduction of complementary feeds were maternal characteristics and practice associated with breastfeeding for less than a year's duration. A study on factors influencing breastfeeding 
duration among Polish women also implicated young maternal age as a factor militating against optimal breastfeeding duration among mothers. ${ }^{[25]}$ No doubt the young mothers are more prone to work pressures and demands which could make them succumb to early cessation of breast feeding in order to focus attention to their work demands. This fact has been documented in a systematic review of breastfeeding in Nigeria by Adewuyi and Adefemi. [26] In the authors' opinion addressing this critical issue of work/breastfeeding conflict among working mothers in our environment will play a pivotal role in optimizing breastfeeding duration among young mothers in prime age of reproduction. An approach to address this may include individualized pre-natal infant feeding counselling which has been found to be very useful in ensuring adherence to infant feeding recommendations. ${ }^{[27]}$

\section{CONCLUSION}

A large number of women in Southeast Nigeria breastfed for up to 12 months and more, however, this still falls below the standard recommendations by the WHO/UNICEF. Reasons proffered for early cessation of breastfeeding were nonscientific. Younger mothers, those who practice non-exclusive breastfeeding or bottle-feeding, or introduce complementary feeds too early, were likely not to breastfeed for up to 1 year. Such factors can be addressed through sustained individualized health education, laying emphasis on the need for not truncating the length of time a child is breastfed, as breastmilk is the bedrock of infant nutrition.

\section{Ethical Considerations}

Ethical clearance for the study was obtained from the Research and Ethics Committee (REC) of Nnamdi Azikiwe University Teaching Hospital, Nnewi Anambra State, South-East Nigeria. The study was explained to the subjects and verbal informed consent was obtained from each respondent to participate in the study.
Permission was obtained from the various Hospital Administrators and Nursing staff in charge of the Well Baby Immunization Clinics used.

\section{Conflict of Interest}

The authors declared that there is no conflict of interest.

\section{Funding}

This research received no specific grant from any funding agency in the public, commercial, or not-for-profit sectors.

\section{Author's Contributions}

EFU and CUO were involved in the conceptualization and development of the research protocol for this study. UE, EFU, CUO, CM, IKU and KNO collected data and facilitated ethical approvals. Data analysis and interpretation were done by CUO and EFU. Initial drafting of the work was carried out by UE and CUO. Critical revision for important intellectual content EFU. All authors were involved in vetting the final version to be published.

\section{Acknowledgement: None}

\section{REFERENCES}

1. WHO (2001) Global strategy for infant and young child feeding. Optimal duration of exclusive breast feeding, WHO A54/INF Doc/4, 1.

2. Martin, Ling dan Blackburn. Review of Infant Feeding: Key Features of Breast Milk and Infant Formula. Nutrients 2016; 8: 279. doi: 10.3390/nu8050279

3. Sunita Koreti, Nitin Prasad. Micronutrient Content of Breast Milk. Journal of Evolution of Medical and Dental Sciences 2014; 3(7): 1633-1638. doi: $10.14260 /$ jemds/2014/2036

4. Huffman SL Combest C. Role of breast-feeding in the prevention and treatment of diarrhea. J Diarrhoeal Dis Res 1990;8(3):68-81. PMID: 2243179

5. Tryggvadottir L, Tulinius H, Eyfjord JE, et al. Breastfeeding and reduced risk of breast cancer in an Icelandic cohort 
study. Am J Epidemiol 2001; 154: 3742 https://doi.org/10.1093/aje/154.1.37

6. Danforth KN, Tworoger SS, Hecht JL, et al. Breastfeeding and risk of ovarian cancer in two prospective cohorts. Cancer Causes Control 2007; 18(5): 517-523. doi: 10.1007/s10552-0070130-2.

7. Isabel $\mathrm{W}$. Breast feeding reduces the risk of breast cancer. BMJ 2002; 325 (7357):

184.

doi: $10.1136 / \mathrm{bmj} .325 .7357 .184 / \mathrm{c}$

PMCID: PMC1143616. PMID: 12143855

8. Amitay EL, Keinan-Boker L. Breastfeeding and childhood leukemia incidence: a meta-analysis and systematic review. JAMA Pediatr 2015; 169: e151025 doi: 10.1001/jamapediatrics.2015.1025.

9. Angelsen NK, Vik T, Jacobsen G, et al. Breastfeeding and cognitive development at age 1 and 5 years. Arch Dis Child. 2001; 85: 183-188 doi: 10.1136/adc.85.3.183.

10. Mortensen EL, Michaelsen KF, Sanders $\mathrm{SA}$, et al. The association between duration of breastfeeding and adult intelligence. JAMA. 2002; 287: 23652371 doi:10.1001/jama.287.18.2365

11. https://www.downtoearth.org.in/news/he alth/study-shows-clear-link-betweenextended-breastfeeding-higher-iqscores-61711 (assessed 23/02/2021)

12. Black RE, Allen LH, Bhutta ZA, et al. Maternal and Child Undernutrition Study Group. Maternal and child undernutrition: global and regional exposures and health consequences. Lancet. 2008;371(9608):243-60 doi: 10.1016/S0140-6736(07)61690-0. PMID: 18207566.

13. Edmond KM, Zandoh C, Quigley MA, et al. Delayed breastfeeding initiation increases risk of neonatal mortality. Pediatrics. 2006;117(3): e380-6. doi: 10.1542/peds.2005-1496. PMID: 16510618.

14. Rollins NC, Bhandari N, Hajeebhoy N, et al. Why invest, and what it will take to improve breastfeeding practices? Lancet. 2016; 387(10017): 491-504. doi: $\quad 10.1016 / S 0140-6736(15) 01044-2$. PMID: 26869576.

15. https://www.who.int/news-room/factsheets/detail/infant-and-young-childfeeding. Accessed 8/2/2021

16. Adebayo Akadri, Oluwaseyi, Odelola. Breastfeeding Practices among Mothers in Southwest Nigeria. Ethiop J Health Sci.2020;30(5):697. doi: http://dx. doi.org/. 10.4314/ejhs.v30i5.

17. Oni GA. Breast-feeding pattern in an urban Nigerian community. Journal of Biosocial Science. 1987;19(4): 453-62. doi: 10.1017/s0021932000017090.

18. Rehan N, Abashiya AK. Breastfeeding and abstinence among Hausa women. Stud Fam Plann. 1981;12(5):233-7. PMID: 7348479

19. Królak-Olejnik B, Błasiak I, Szczygieł A. Promotion of breastfeeding in Poland: the current situation. J Int Med Res. 2017;45(6):1976-84.doi: 10.1177/0300060517720318

20. Robert E, Coppieters Y, Swennen B, et al. Breastfeeding duration: a survival analysis-data from a regional immunization survey. Biomed Res Int. 2014; $\quad 2014$ : 529790. https://doi.org/10.1155/2014/529790.

21. Isenalumhe AE, Oviawe O. Prelacteal feeds and breast-feeding problems. Indian J Pediatr. 1987;54(1):89-96. doi: 10.1007/bf02751246. PMID: 3557596

22. Mudambi SR. Breast-feeding practices of mothers from Mid-Western Nigeria. J Trop Pediatr. 1981;27(2):96-100 doi: 10.1093/tropej/27.2.96.

23. Onubogu CU, Onyeka IN, Esangbedo DO, et al. Changes in breastfeeding and nutritional status of Nigerian children between 1990 and 2008, and variations by region, area of residence and maternal education and occupation. Paediatrics and International Child Health 2016, 36:4, 248-259. doi: 10.1179/2046905515Y.0000000048

24. Osuorah DIC, Ekwochi U, Ndu KI, et al. Early Cessation of Breastfeeding: A 
Neglected Nutritional Challenge among Infants. International Journal of Clinical Nutrition 2015; 3(1): 12-16. doi:10.12691/ijcn-31-3

25. Tracz J, Gajewska D. Factors Influencing the Duration of Breastfeeding among Polish Women. Journal of Mother and Child. 2020; 24 (1): 39-46. DOI: https://doi.org/10.34763/jmotherandchil d.2020241.2006.000007

26. Adewuyi EO, Adefemi K. Breastfeeding in Nigeria: a systematic review. Int $\mathbf{J}$ Community Med Public Health 2016; 3: 385-96. DOI: 10.18203/23946040.ijcmph20160421
27. Onubogu CU, Ugochukwu EF, Egbuonu I, et al. Adherence to infant-feeding choices by HIV-infected mothers at a Nigerian tertiary hospital: the pre-"rapid advice" experience. S Afr J Clin Nutr 2015;28(4):180-186. doi: $10.1080 / 16070658.2015 .11734558$

How to cite this article: Ekwochi U, Ugochukwu EF, Onubogu CU et.al. Breastfeeding duration and related factors among mothers in Southeast Nigeria. Int $J$ Health Sci Res. 2021; 11(5): 305-312. DOI: https://doi.org/10.52403/ijhsr.20210548 